\title{
Research on the Influencing Factors of the Development of Producer Services in Shaanxi Province
}

\author{
ZHENG Yaoqun ${ }^{1}$, YU Quanming ${ }^{2}$ \\ ${ }^{1,2}$ Xidian University, School of Economics and Management, 266, Xi Feng South Road, Xian 710126, China
}

\begin{abstract}
According to the data from the year of 1994 to 2014 about the development of producer services of Shaanxi province, and the development status and characteristics of producer services in Shaanxi province, this paper analyzes the factors that influence the development of producer services in terms of supply: capital investment and labor input. This paper uses ADF test, Johansen co-integration test, VAR model and granger causality test, to analyze the impact of capital investment and labor input on producer services, and finds that there is a long-term stable balance relationship between producer services and capital investment and labor input. Capital input and labor input contribute to producer services. Whether in the long run or short term, capital investment plays a role in promoting the development of producer services, while in the short term, labor input hinder the development of producer services.
\end{abstract}

Keywords: Producer Services; VAR Model; Co-integration Test; Granger Causality Test, JEL: F719

\section{Introduction}

Since the 1980's, producer services gradually becomes the highlight of western developed countries' economic development, producer services gradually replaces manufacturing industry as the main driving force and source of innovation. The state proposed and implemented policies such as "western development" and One Belt And One Road construction, to drive the economic development of western region especially Shaanxi. With the increasing role of producer services in promoting economic development, research on producer services has been gradually enriched. Because most of these studies are based on developed countries or regions of producer services, and focus on the role of producer services development in manufacturing development, few give advice on how to promote the development of producer services from the supply side.

The concept of producer services was first proposed by Machlup(1962), which argues that producer services must be an industry of producing knowledge. Browning and Singelmanin (1975) the functional classification of services also puts forward the concept, believes that producer services includes finance, insurance, legal, business services, brokerage, etc., which has knowledge and intensive characteristics and provides specialized services for customers. The concept of producer services is summarized, and productive service industry refers to the aggregate of productive service enterprises (Gu Naihua et al., 2006).

With the increasing role of producer services in economic development, the research on Producer services are becoming more and more abundant. The development of producer services promotes the integration of technological progress and economic growth. Producer services can guide technology into the production process, promote social division of labor, and influence the direction of technological innovation (Chen Baoqi and Li Weiren, 2006). Poducer services play an important role in China's economic growth through the analysis of the panel data from 1997 to 2006 (Zhang Yabin and Liu Liang jun, 2008). By analyzing the data of China from 2004 to 2011, the development of Producer services are not related to economic growth ( $\mathrm{Li}$ Xiaole, 2013).

The rapid development of any industry requires the support of strong capital, which requires the support of a large amount of funds due to the improvement of the research level and the extension of the industrial chain. Producer services are favoured by investor, from the value chain theory, because it can generate more profits. Through empirical analysis panel data from 1999 to 2008, finds that the value chain of each link does not creating the same profits, the additional value of upstream and downstream of the whole value chain link is higher, that is, productive services can generate more profits and thus attract more capital to producer services (Hu Guoping and $\mathrm{Xu}$ Xianfeng, 2012). By constructing the space panel econometric model, believe that underdeveloped regions in introduction of producer services can make full use of the developed areas of capital investment, promote technological progress and industrial upgrading, and developed areas can expand the scale economy of their producer services and speed up urban transformation (He Qingsong et al., 2012). By trend development of producer services and increasing the region competitiveness, believes that the development of producer services depends on the support of the labor force, and the introduction of high-quality labor force is conducive to promoting the rapid development of producer services(Wang Baolun and Lu Yanhong, 2007; Wang Diankai and He Yuge, 2013).

This paper is based on the relevant research literature, starting from the supply of producer services in Shaanxi Province, to explore the development of producer services in Shaanxi. 


\section{International Journal of Science and Research (IJSR) \\ ISSN (Online): 2319-7064}

Index Copernicus Value (2015): 78.96 | Impact Factor (2015): 6.391

Producer services are the premise and foundation of the improvement of manufacturing productivity. Without developed producer services, a strong competitive manufacturing sector cannot be formed. The development of producer services can improve the division of labor, reduce the transaction cost of social economy operation, and promote economic growth. This paper analyzes the influence of capital input and labor input on the production services in Shaanxi.

At present, producer services of Shaanxi mainly focus on the traditional producer services, such as transportation, warehousing and postal, financial and wholesale and retail industries. These industries need a lot of capital investment in order to achieve rapid development. For emerging industries, the proportion of initial investment is relatively large, for example, the investment in scientific research equipment, but most emerging producer services are knowledge intensive, and the basic feature of knowledge is that they can be reused, such as standardized computer software, which costs almost nothing, and it brings economies of scale far beyond other industries. The investment in the emerging producer services will improve the level of scientific research and technological innovation, improve the professional level of producer services, and help the long-term development of the economy. Development will require more capital investment, and more capital input will bring more output and higher efficiency, lower transaction costs for businesses. Therefore, the more capital investment in producer services will promote the development of producer services.

Hypothesis (1): the more capital investment in producer services, the faster producer services will develop. Labor force is an important input factor in any industry, especially producer services. The input of labor force is directly related to the development speed and scale of the industry. Scale expansion is conducive to the professional development of producer services and the overall efficiency of the industry. The increase in labor input has strengthened market competition, providing better quality services and lower transaction costs. Producer services are highly dependent on talent and high-quality talent in a certain extent determines the competitiveness of productive service industry, service ability, development potential and market position, and also determines the supply quantity and level of productive services.

Hypothesis (2): the more labor input in producer services, the faster development of producer services.

\section{Materials and Method}

\subsection{Data preparation and introduction to influencing variables}

In view of the availability of data, this paper selects the data from the year of 1994 to 2014 from the national statistical database and the Shaanxi statistical yearbook. The development of producer services in Shaanxi province is measured by the added value of productive service industry. Capital input is measured by fixed capital inputs in producer services. Labor input is measured by the number of employees in producer services.

\subsection{Method}

According to cobb-douglas production function:

$$
Y=A K^{\alpha} L^{\beta}
$$

Where:

Y-Output

A-Technological progress

$\mathrm{K}$ - Capital input

L-Labor input

Producer services, labor levels, and capital inputs have similar relationships. As capital input and labor input permeate all stages of technological progress, this paper assumes technological progress $A=1$, that is, the regression analysis is described as follow:

$$
P S=I N V E S T M E N T^{\alpha} L A B O R^{\beta}
$$

To prevent heteroscedasticity, the logarithm of the equation is on both sides. The formula is:

$$
L N P S=\alpha L N I N V E S T M E N T+\beta L N L A B O R+\varepsilon
$$

Where:

PS - The added value of productive service industry

INVESTMENT_Fixed capital inputs

LABOR - Number of employees in producer services

$\alpha, \beta$-The coefficients corresponding to each variable

$\varepsilon$-Stochastic disturbed term

\section{Results and Discussion}

\subsection{Augmented dickey-fuller test}

To study whether there is a long-term relationship between economic variables, we must first test the stationarity of the time series. If a non-stationary sequence is used for regression, it will result in a pseudo-regression. When the variables are not stable, the traditional statistics are biased, for example, t、F、R2. In order to ensure no spurious regression, the ADF test method is used to test the stability of the variables. Results of ADF test are shown in table 1 and 2 .

Table 1: Original sequence ADF test results

\begin{tabular}{|c|c|c|c|c|}
\hline variable & $\begin{array}{c}\text { ADF test } \\
\text { statistic }\end{array}$ & $\begin{array}{c}\text { The } \\
\text { critical } \\
\text { value of } \\
\text { the } 1 \% \\
\text { level }\end{array}$ & $\begin{array}{c}\text { Percentage } \\
(\%)\end{array}$ & conclusion \\
\hline $\ln P S$ & -0.524599 & -3.808546 & $86.67 \%$ & Non-stationary \\
\hline
\end{tabular}

Volume 6 Issue 7, July 2017 www.ijsr.net 
International Journal of Science and Research (IJSR)

ISSN (Online): 2319-7064

Index Copernicus Value (2015): 78.96 | Impact Factor (2015): 6.391

\begin{tabular}{|l|l|l|l|l|}
\hline ln Investment & -3.014787 & -3.857386 & $5.25 \%$ & Non-stationary \\
\hline
\end{tabular}

\begin{tabular}{|l|l|l|l|l|}
\hline LABOR & -2.350023 & -3.808546 & $16.73 \%$ & Non-stationary \\
\hline
\end{tabular}

Table 2: First order difference test results

\begin{tabular}{|c|c|c|c|c|}
\hline variable & $\begin{array}{c}\text { ADF test } \\
\text { statistic }\end{array}$ & $\begin{array}{c}\text { The critical } \\
\text { value of the } \\
1 \% \text { level }\end{array}$ & $\begin{array}{c}\text { Percentage } \\
(\%)\end{array}$ & conclusion \\
\hline DlnPS & -4.261108 & -3.831511 & 0.41 & stationary \\
\hline DlnInvestment & -7.022596 & -3.831511 & 0.00 & stationary \\
\hline DlnLABOR & -5.444550 & -3.831511 & 0.03 & stationary \\
\hline
\end{tabular}

According to table 1 and 2 , the original sequence of variables is nonstationary at the $1 \%$ level, and the first difference is stable at the $1 \%$ level. So the results indicate that the sequence is first order differential stationary sequence.

\subsection{The establishment and estimation of VAR model and Results analysis}

VAR model is an unstructured model, that is, the relationship between variables is not based on economic theory. The VAR model constructs the model by using each of the endogenous variables in the system as a function of the lag terms of all endogenous variables in the system. According to the FPF criterion, the AIC criterion, the SC criterion and the HQ criterion, the optimal lag length is 4 order. In this paper, the VAR model with unconstrained constraint is adopted, and the equation is as follows:

$$
\begin{aligned}
\text { LNPS }_{t}= & 3.848389+0.517955 \text { LNPS }_{t-1}+0.149950 \text { LNINVESTMENT }_{t-1}+0.017121 \text { LNLABOR }_{t-1} \\
& -0.124415 \text { LNPS }_{t-2}-0.0192559 \text { LNINVESTMENT }_{t-2}-0.191352 \text { LNLABOR }_{t-2} \\
& +0.0349546 \text { LNPS }_{t-3}-0.007602 \text { LNINVESTMENT }_{t-3}-0.493767 \text { LNLABOR }_{t-3} \\
- & 0.284512 \text { LNPS }_{t-4}+0.079341 \text { LNINVESTMENT }_{t-4}+0.332083 \text { LNLABOR }_{t-4}
\end{aligned}
$$

The goodness of fit is 0.966423 , This shows that the overall fitting effect of the equation is better. According to equation (4), the influence of the Shaanxi productive service industry on itself is alternated with the positive influence and negative influence. This may be because companies are still adapting to the impact of producer services, and are constantly adjusting. The impact of capital input and labor input on producer services in Shaanxi was positively affected first and then negatively, and then shifted to positive impact. This is because the government short-term policy can promote the development of producer services, but also can hinder the role to the development of producer services, after digest industry adjust its adverse effect, the end the government policy still can promote the development of producer services.

\subsection{Johansen co-integration test and Results analysis}

Co-integration refers to two or more time series not stable, but its linear combination shows the stability, so these variables have long-term stable relationship, that is, co-integration relationship. In the analysis of the lag structure, the inverse of the root of AR characteristic polynomial in VAR model is less than 1, which is in the unit circle, so the VAR model is stable. The sequence first order and VAR model are stable, and the Johansen co-integration test is conducted. The co-integration test results of related variables are shown in table 3 and table 4 .

Table 3: Trace statistics co-integration test

\begin{tabular}{|c|c|c|c|}
\hline $\begin{array}{c}\text { Number of null } \\
\text { hypothesis }\end{array}$ & $\begin{array}{c}\text { Trace } \\
\text { statistic }\end{array}$ & $\begin{array}{c}5 \% \text { critical } \\
\text { value }\end{array}$ & $\begin{array}{c}\text { Percentage } \\
(\%)\end{array}$ \\
\hline 0 & 33.46577 & 29.79707 & 1.81 \\
\hline At most one & 8.366116 & 15.49471 & 42.71 \\
\hline At most two & 1.151466 & 3.841466 & 28.32 \\
\hline
\end{tabular}

Table 4: Max-Eigen statistics co-integration test

\begin{tabular}{|c|c|c|c|}
\hline $\begin{array}{c}\text { Number of null } \\
\text { hypothesis }\end{array}$ & $\begin{array}{c}\text { Max-Eigen } \\
\text { statistic }\end{array}$ & $\begin{array}{c}5 \% \text { critical } \\
\text { value }\end{array}$ & $\begin{array}{c}\text { Percentage } \\
(\%)\end{array}$ \\
\hline 0 & 25.09965 & 21.13162 & 1.31 \\
\hline At most one & 7.214638 & 14.26460 & 46.41 \\
\hline At most two & 1.151477 & 3.841466 & 28.32 \\
\hline
\end{tabular}

According to table 3 and 4, the hypothesis — "at most one" co-integration relations, whether in the trace statistic test or in the test of the maximum eigenvalue statistic, The trace statistics and the maximum eigenvalue statistics are less than the critical values of each $5 \%$, so we cannot reject the original hypothesis. Therefore, there is a co-integral relation, which is:

$$
L N P S=0.322935 L N I N V E S T M E N T+0.028085 L N L A B O R+\varepsilon
$$

According to Co-integration equation, LNINVESTMENT and LNLABOR increases by $1 \%$ respectively, and LNPS increases by $32.2935 \%$ and $2.8085 \%$ respectively. This shows that there is a balanced relationship between long-term producer services and capital input and labor input, capital input and labor input can promote the 


\section{International Journal of Science and Research (IJSR) \\ ISSN (Online): 2319-7064}

Index Copernicus Value (2015): 78.96 | Impact Factor (2015): 6.391

development of producer services, and capital investment plays a more significant role in promoting the development of producer services than labor input in producer services.

\subsection{Granger causality test and Results analysis}

The Granger causality test can be used to determine whether there is a causal relationship between the economic variables and the direction of the impact. The test idea is that if the change in $\mathrm{X}$ causes a change in $\mathrm{Y}$, the change in $\mathrm{X}$ should occur before the $\mathrm{Y}$ changes.

According to table 5, the results of Granger causality test shows that capital input is the cause of the development of producer services, but the development of Producer services are not the cause of capital input. Labor input is the cause of the development of producer services, but the development of Producer services are not the cause of labor input. This shows that capital investment and labor input have a greater impact on the development of producer services, while the development of producer services has little impact on capital investment and labor input.

Table 5: The results of Granger causality test

\begin{tabular}{|c|c|c|l|}
\hline Original hypothesis & $\begin{array}{c}\mathrm{F} \\
\text { statistic }\end{array}$ & $\begin{array}{c}\text { Percentage } \\
(\%)\end{array}$ & conclusion \\
\hline $\begin{array}{c}\text { LNPS does not Granger } \\
\text { Cause LNINVESTMENT }\end{array}$ & 0.96996 & 47.43 & accept ion \\
\hline $\begin{array}{c}\text { LNINVESTMENT does not } \\
\text { Granger Cause LNPS }\end{array}$ & 3.74354 & 5.30 & rejection \\
\hline $\begin{array}{c}\text { LNPS does not Granger } \\
\text { Cause LNLABOR }\end{array}$ & 0.35297 & 83.52 & accept ion \\
\hline $\begin{array}{c}\text { LABOR does not Granger } \\
\text { Cause PS }\end{array}$ & 3.20132 & 7.57 & rejection \\
\hline
\end{tabular}

\section{Conclusion}

Based on cobb-douglas production function, this paper first introduces the related theory and model, and puts forward the corresponding model and hypothesis, then we establish a VAR model based on the data from the year of 1994 to 2014, this paper analyzes the impact of capital input and labor input on producer services in Shaanxi. We through ADF test, Johansen co-integration test and granger causality test get the following conclusion:

1) The more capital investment in producer services, the faster producer services will develop. The more labor input in producer services, the faster development of producer services.

2) There is a long-term equilibrium relationship between producer services and capital investment and labor input. Capital input and labor input can promote producer services, and capital investment plays a more important role in promoting the development of producer services than labor input.

3) Whether long-term or short-term, capital investment plays a role in promoting the development of producer services. In the long run, labor input plays a role in promoting the development of producer services. In the short run, labor input has hindered the development of producer services.

This is because a large number of ordinary labor force into the market, not only reduces the overall quality of workers, but also seriously affected producer services, especially the emerging producer services. The labor force is still the factor that promotes the development of producer services when the producer services survive the adverse effects of the labor force.

\section{Acknowledgements}

This research is supported by Shaanxi province social science fund project "research on interactive development of producer services and manufacturing industry in Shaanxi d36 (2014); Xi 'an science and technology plan soft science project "the resources and environment under the double constraints of xi 'an to undertake research on industrial transfer (SF1408-1).

\section{References}

[1] MACHLUP, F. The Production and Distribution of Knowledge in the United States[ M]. New Lersey: Princeton University Press, 1962.

[2] BROWNING, J. Singleman, The Emergence of a Service Society[M]. Springfield, 1975.

[3] Gu Naihua, Bi Doudou, Ren Bingwang. "Interactive Development of Producer Services and Manufacturing: a Literature Review “. Economist, 2006, (6), pp. 35-41, 2006.

[4] Chen Baoqi, li Weiren. "Development of Producer Service Industry and the Transformation of China's Economic Growth Mode". Journal of Graduate School of Chinese Academy of Social Sciences, 2006, 156(06), pp.86-90, 2006.

[5] Zhang Yabin, Liu Liangjun. "Research on the Impact of Producer Services on China's Economic Growth: An Empirical Analysis Based on Panel Data from East, Central and West". Forum of World Economics \& Politics, 2008, (04), pp.79-86, 2008.

[6] Li Xiaole. "Government Scale, Producer Services and Economic Growth: Based on Panel Data Analysis of 206 Cities in China". Journal of International Trade, 2014, (05) pp.105-112, 2014.

[7] $\mathrm{Hu}$ Guoping, Xu Xianfeng. "The Mechanism and Influencing Factors of the Export-oriented Development of Urban Producer Services. Based on Panel Data of 15 Sub-provincial Cities from 1999 to 2008". Macroeconomic Study, 2012, (3), pp.40-47, 2012.

[8] He Qingsong, Zhang Peiying, Yuan Shengbo. "Spatial Econometric Technology Spillover Effect of Productive Service Industry FDI Analysis". Economic Problem, 2012, (01). pp.83-86,2012.

[9] Wang Baolun, Lu Hongyan. "Producer Services and the Promotion of Regional Industrial Competitiveness". Inquiry into Economic Issues, 2007, (07).pp.11-15,2007

[10] Wang Diankai, He Yuge. "An analysis of the development trend and growth performance of producer

\section{Volume 6 Issue 7, July 2017 www.ijsr.net}




\section{International Journal of Science and Research (IJSR) \\ ISSN (Online): 2319-7064}

Index Copernicus Value (2015): 78.96 | Impact Factor (2015): 6.391

services”. Economic Review, 2013, (02),pp.76-80,2013.

\section{Author Profile}

YU Quanming (1990--), male, Xinyang, Henan, Xidian University, Xidian University, School of economics and management, master degree.

Li Quan Zheng Yaoqun (1978--), female, Liquan, Shaanxi, Xidian University, School of economics and management, associate professor, doctor of economics, supervisor of master's degree

Volume 6 Issue 7, July 2017 www.ijsr.net 